\title{
Concern Over the Future of the Nation - A Discourse Analytical Study on Changes in Russian Demographic Policy in the Years 2000-2010
}

\author{
EVELIINA HEINO, M.A., (Linguistics and Social Sciences), \\ Researcher/Planning Officer \\ Palmenia Centre for Continuing Education, University of Helsinki, Finland
}

\begin{abstract}
This article discusses statements on demographic policy issued by the Russian state leadership in the years 2000-2010. During the years covered in this study, there has been an increase in publicly expressed concern over the state of the population, i.e. low birth rate in conjunction with high mortality. This concern over population as a research topic is made relevant, first of all, by the acute nature it has as a social political issue. Secondly, it has a variety of connections with other important areas, such as family life, gender, and labor market.

The research material consists of annual speeches delivered by Russian state leadership, as well as three official long-range plans, in which discussion concerning the demographic situation is given a central role. Discourse analysis was adopted as the theoretical framework to guide the interpretations because it facilitates observation of the linguistic mechanisms used to define certain phenomena as problems, and to offer other phenomena as solutions to these problems.

The analysis revealed three types of discourse, each a part of a broader demographic policy discourse, and each defining Russian demographic policy in its own characteristic way. In the "Serious Problem" discourse, the demographic phenomenon is taken apart and rationalized, while awareness of an impending crisis is created. The "State Support" discourse offers solutions to a defined problem and lends legitimacy to state leadership as a successful executor of these solutions. The "Family Centered" discourse argues for the traditional family model, according to which legal marriage, reproduction and high fertility rate are key values.
\end{abstract}

Keywords: Russia, demographic policy, discourse analysis, discourse

\section{Introduction}

Over the past decades, global demographic development trends and the concern caused by them have been at the center of political discussion. Population dynamics is considered to be a major factor affecting society. On the one hand, population growth is seen as an obstacle to Third World development. On the other hand, the decline in 
population and the fall in birth rates taking place in industrialized countries are also considered to have social political relevance. Several shared factors underlie the current population dynamics of industrial nations, including modernization, changes in the family model, declining birth rates and the aging of the post-war generation. At the same time, different countries also have certain characteristic features that affect demographic development. Regarding such factors, Russia is an interesting case, since its birth rate has declined to the level of other industrial countries, while the mortality rate has remained at the level of many developing nations. To describe the current situation, the term "demographic crisis" (демографический кризис) has been adopted in Russia, referring to the reduction in population size (Višnevskij 2009).

Analysing Russian population discourses is of current interest for several reasons. First, improving the demographic situation has become one of the most central national projects in Russia over the period covered in this study. Secondly, the topic is multifaceted, as the discourse on birth rates touches upon issues of family life, gender and equality, as well as the extent of the state's intrusion into a traditionally private domain, the sex life of its citizens. In addition, the discourse reaches into the spheres of social policy and national economy, as concerns are raised over the future of the economy, the labor market and the social security system (see Vuori 2001). Thirdly, there is an abundance of quantitative information regarding the birth rate, mortality and the effects of a number of societal interventions on the demographic situation, but the topic has received little attention in terms of qualitative research, especially from the discourse analytical viewpoint. Such research has societal relevance, as the form political questions and problems take is often linked to the specific expressions used in discussing them. The discourse theoretical viewpoint can provide us with deeper insight into the characteristic openness of political questions, and the way they are susceptible to being defined by parties that wish to suggest solutions to such questions.

\section{The demographic situation in Russia}

Population decline started to become visible in Russia in the early 1990s. At that point, mortality exceeded the birth rate. The trends underlying this development are partly the same as in many Western European countries, including a change in the family model, low birth rate, and the aging of the post-war generation. (UN 2008, p. 6.) However, there are also characteristics behind the decline that are specific to Russia. While the total fertility rate has fallen to the level of other industrialized countries, for example in 2008 it was 1.4 in Russia and 1.8 in Finland, mortality has remained at a high level in Russia. (Rosstat 2011; Tilastokeskus 2010).

According to Andreev et al. (2003) between 1987 and 1994, and since 1998, life expectancy at birth has declined in the Russian Federation, while in European counties life expectancy has been improving steadily. In 2008 the average life expectancy in 
Russia was 61.8 years for males and 74.2 years for females (Rosstat 2008). In Finland average life expectancy at the same year was 76.3 years for males and 83.0 years for females (Rapo 2008). While in 1989 the census showed the total population to be 147 million, in 2010 it had declined to 142 million. (Rosstat 2011.)

Demographic changes develop over long time spans, and the entire history of the $20^{\text {th }}$ century has a significant role in the creation of the current situation. There are, however, views presented in the scientific literature that suggest other factors as contributing to the crisis. These are not seen as isolated phenomena, but as mutually interconnected. These factors include: 1) The collapse of the Soviet Union and the change of the political system, followed by a drastic change and uncertainty in living conditions, 2) Insufficient health care and medical services (Višnevskij 2009, p. 15; UN 2008, p. 8). 3) Alcohol consumption particularly among working-age men. (Leon 2009, pp. 1630-1636; Halturina and Korotaev 2006, p.10). 4) Chronic diseases such as cardiovascular diseases and cancer (Vallin et al. 2005; Ulkoasiaiministeriö 2011, p.8.). 5) Changes in the family model, which are, decline in birth rates and registered marriages, growth of divorces, cohabitation and other forms of relationships etc. (Volkov 1999, pp.48-50; Zaharov 2005, pp.124-140; Zaharov and Ivanova 2004).

According to a number of different forecasts, the Russian population is expected to decline dramatically. According to the 2007 listing of the U.S. Census Bureau, Russia is the eighth most populous country in the world, but will lose its place among the ten most populous countries in the coming decades. The Federal State Statistics Service also predicts that in 2030 the size of the Russian population will be 139 million. In contrast, the international Population Reference Bureau estimates the Russian population to fall to 129 million in 2030. (Rosstat 2009: Population Reference Bureau 2008.) The predictions vary greatly, but the population is expected to decline at an average rate of $0.3-0.8$ million per year, depending on birth rate and immigration (Elizarov 2002a). The population decline is expected to result in a number of social and economic problems. This situation poses many challenges, the greatest of which are perceived to be workforce shortages and maintaining economic competitiveness, as well as issues of nationality and national security (Poslanije 2006).

\section{Demographic Policy in Russia}

In the Soviet era, the centralized government assumed all responsibility for guiding demographic and social policies and distributing resources. During this period, the state guaranteed a reasonable standard of living, social and health services, jobs etc. (Smirnov and Sidorova 2004; Sidorina 2005). In the 1990s, after the collapse of the Soviet Union, the framework within which social policy functions changed radically. The shift from planned economy to market economy demanded the development of new kinds of funding mechanisms and practices. The changes that took place in the 
1990s had numerous effects on social policy. Universality partly disappeared, and the support that came from the state started to show signs of becoming marginal. (Sidorina 2005; Smirnov and Sidorina 2004, pp. 230-231; Hartšenko 2009, p. 312.) In the 1990s, extensive numbers of immigrants also started moving into Russia. This demographic change required new laws and practices (Jarošinskaja 2007). Since the 1990s, there has been an increase in the resources allocated to developing demographic research, such as devising plans regarding demographic development. Local plans to boost birth rates have been made since the collapse of the Soviet Union. However, the first national, official plan for demographic development in Russia was published as late as in 2001. (Hartšenko 2009, p.312.)

It has been argued that the formation of demographic policy since 2000 is linked to the development of the market economy, the aggravated social and health problems and the acquisition of international knowledge and experience in public health work (Aarva and Pietilä 2010). In 2001, the Russian leadership approved the "The Concept of Demographic Development in Russian Federation until 2015” (Концепция демографического развития Российской Федерации на период до 2015 года), prepared by the Ministry of Labor and Social Development. This was the first official document that contained general description of the goals, principles and priorities of demographic policy. In this conceptualization, the most important goals of demographic policy were defined as to stabilize Russia's population level and to create conditions for demographic growth. Additionally, the law on support for families was changed in 2001, raising social benefits to families with children by several hundred percent. The amounts paid as benefits were very small, but they can be seen as having symbolic value (Elizarov 2011b).

In the years 2000-2005, the priorities of the Russian Federation primarily concerned the reorganizing of legal-administrative and economic mechanisms after the collapse of the Soviet Union, so demographic issues got somewhat less attention. During these years there was public discussion about the demographic situation being alarming, but concrete, large scale measures to improve the situation were not taken. The state leadership only raised demographic problems to the top of the list of priorities as late as in 2006. President Vladimir Putin talked about the Russian demographic situation in his annual speech, and suggested a number of alternative ways to resolve the situation. During the same year several different kinds of action were taken by the state to rectify the problems. For example, mothers who gave birth to a second child started receiving a new type of state benefit, called "Maternity Capital" (Материнский капитал), provided in the form of state-administered financial aid. Between 2007-2017, any mother who already has one child or more and either gives birth or adopts another child - thus increasing the number of children in the family to two or more - is entitled to receive this aid. Father can also receive this aid, but there are specific requirements for it. Both caretaker and child are required to be Russian citizens. The application for Maternity Capital is made to the pension institute of the parent's registered place of 
residence, and the precise sum is defined on the basis of the annual monetary value. For example, in 2007 the benefit was 250000 roubles, and in 2011 it was 365700 roubles. Maternity Capital can be received until the child turns three, and it can be used for example on improving living conditions (e.g. acquiring a new apartment), raising the mother's work-based pension, or educating a child under 25 years of age, if the education takes place within Russia. (Law 29.12.2006.)

On the same year, the nationwide "Health" project (Здоровье) was also launched. The program included handing out "Childbirth Certificates" to women during weeks 28-30 of their pregnancy. The certificate consists of health service vouchers that can be used to pay for health services during pregnancy, health care costs related to delivery, and visits to children's clinics up to age one. The total value of the Childbirth Certificate is 10000 roubles, and it is paid out of the state budget. The purpose of the program is to get the attention of actors that provide health care, and to motivate them to offer high quality health services. (Decree 1.1.2006.)

In 2006 "The national program for the demographic development of Russia until the year 2015" was published. National goals presented in the document were to reduce mortality, to formulate effective immigrant policy and to increase birth rates. This document contains implementation stages and goals presented in it are parallel to the goals presented in The Concept of Demographic Development in Russian Federation until 2015 and presentation by Russian President to the Federal Assembly of the Russian Federation in 2006.

Heated debate on demographic policy continued in 2007, and on November $11^{\text {th }} 2007$ a new Concept of Demographic Development of Russian Federation until 2025 came into force (Концепция демографического развития Российской Федерации на период до 2025 года). The policy presented in the concept emphasizes population growth and aims to increase Russia's population to $142-143$ million people by 2015 and create the conditions for an increase to 145 million by 2025 . The policy aims as well to improve living standards and increase average life expectancy to 70 years by 2015 and to 75 years by 2025 . The concept contains description of the principles, objectives, and means to attain those objectives and implementation stages. This makes it notoriously more detailed document than the previous concept. (Kontseptsija 2007.)

Year 2008 was named "The Year of the Family" (Decree 14.6.2007). This nomination can be seen as bringing the family into the center of public attention. During the Year of the Family, there was an increase in research related to family policy, as well as in cooperation between state leadership, the private sector and actors in the fields of culture and sports. The Year of the Family executive committee had members representing many different sectors. The goal set for the theme year was to support the family institution, family values and parenthood. The propagation of family values took place in the form of book publishing and advertising in a variety of media. In addition, 
posters promoting family values were placed in public spaces, on the outside walls of buildings, in the subway tunnels, and so forth. Festivals, exhibitions, competitions and charity fundraising events were also arranged. In addition to these, attempts were made to raise general awareness of the family institution by publishing a variety of research reports and statistics concerning families.

\section{Data and methods}

The research material covered in this study includes: (1) Presentations by Russian Presidents to the Federal Assembly of the Russian Federation in the years 2000-2010, ten presentations in total (Послание Президента Федеральному Собранию). (2) Two Concepts of Demographic Development in Russian Federation until 2015 and 2025 (Концепция демографического развития Российской Федерации). (3) Тhe national program for the demographic development of Russia until the year 2015 (Haциональная программа демографического развития России).

Studying the speeches and official documents of state leadership is justified because state administration arguable has the greatest influence in initiating and shaping the birth rate discussion, in influencing the public opinion, and in instigating changes in demographic policy. The selection of the time frame for this study can be justified by the clear actualization of demographic issues during this particular period. This means, above all, that concern regarding the future of the nation has become more pronounced, that family centered ideology has made a comeback, and that state-controlled incentives are emphasized as a means to guide demographic development.

The content of most of my material has been influenced by Vladimir Putin, President of Russia in present time and in the years 2000-2008. Between years 2008-2011, the annual speech has been given by President Dimitri Medvedev. These two politicians have been on the same lines in terms of demographic programs, and Medvedev has followed the demographic outlines laid down by Putin. The material has been collected from the official internet pages of the Russian Federation, where all legislation, political outlines and speeches by state leadership concerning Russian domestic and foreign politics are published (www.kremlin.ru).

The material is analyzed using the tools of discourse analysis. An essential part of discourse analysis is seeing discourses as narratives that shape our perceptions of the world. However, discourses do not arise in a vacuum. They are always articulated by an actor located in a certain socio-political situation. (Fairclough 1995, p.76.) In discourse analytical research, relationships between knowledge and power are at the focus of attention. Thus the prevailing knowledge at any point in time directs our thinking and action. Discourses can be used to shape people's perceptions, to make them internalize something and to make them act in a particular way, thus realizing 
power through discourse. In addition, discourses may exclude certain possibilities for action and place limitations on action. Discourses bring up issues through certain social practices, which puts the persons and institutions that produce discourses in an important position. (Foucault 1978, pp.30, 50-51.)

I here understand discourse as a form of representation. Representation can be defined as presenting a social practice from a particular perspective. The prefix "re-" points to the fact that the objects being referred to by linguistic devices are not immediately present, but represented by some actor (See e.g. Lehtonen 1996, p.45). When discourse has been given the concrete definition of one form of representation, different discourses can be named, so that their viewpoints and mutual differences can be pointed out. An underlying idea is that a single phenomenon can be presented in different ways in separate discourses (Fairclough 1995, p. 77).

Furthermore, discourse analysis is useful for showing how certain issues are brought to the forefront, from a certain point of view, while leaving other issues hidden. In this material, a certain kind of reproductive behavior is encouraged, and certain values and ways of life are promoted. People are not exactly forced to do anything, but they are guided in a certain direction, so the definitions and meanings that arise in the discussion can influence people's attitudes towards these issues.

\section{Demographic policy discourses}

The central question posed by this article concerns the form that Russian demographic policy takes within the statements of the state leadership in the years 2000-2010. The research questions are:

- How is the demographic situation represented, i.e. how is the low birth rate and on the other hand the relatively low average life expectancy presented, and how is it discussed?

- What factors are seen as underlying these problems?

- What measures are suggested in order to solve these problems?

- How are these measures justified?

I intend to analyze constructions of demographic policy, as well as pre-existing assumptions, and culturally self-evident "truths" underlying them. As the analysis proceeds further, my goal is to identify and name the strong discourses that can be extracted from this material. At the first stage of my analysis I read thoroughly all research material drawing attention to the themes and expressions which appeared repeatedly in the data. These operated as the units of my analysis. At the second stage I conceptualized features of different discourses. This was implemented by classifying the units of analysis accord- 
ing to their mutual similarities and differences. The guiding principle of classification was the question, in which various forms is the subject matter being represented, i.e. what are the different perspectives through which the demographic situation is viewed. As a result, I was faced with several classes of features each containing a number of units. The third stage consisted of the formulation of discourses by conjoining various features that cohered with each other into larger wholes. In my analysis, I found three such wholes, which I named as the Serious Problem discourse, the State Support discourse and the Family Centered discourse. It would have been possible to split them into smaller parts, but to my view, these broader discourses are more able to catch the multiplicity of phenomena and to reveal the internal logic behind them. In addition, broader discourses do not require so much artificial division of data.

In the following text I have added citations which I believe manifest the essential aspects of each feature in a given discourse. All citations are numbered and indented, so they can be traced. In the next chapters all three discourses are being presented separately.

\section{The Serious Problem discourse}

In the Serious Problem discourse, the demographic situation is approached in a problembased manner. This problem is presented as being objectively verifiable, its causes as analyzable and its consequences predictable. In used data the demographic situation is defined as a problem of great severity that concerns the entire country. The seriousness of the problem is emphasized by using a number of different adjectives, such as "difficult" and "acute". These concepts are used to create collective crisis awareness, as the problem is presented as concerning the whole country and modern Russia, not only a particular section of the population. The Serious Problem discourse attempts to prove the seriousness of the problem, primarily by presenting statistical data, which lends the information an air of credibility.

(1) In the year 2000, 1267 thousand people were born, which is 722 thousand or 1.6 times less than in the year 1990. The fall in birth rate started in the 1960s. The current birth rate is two times lower than that needed to renew generations: the average number of total fertility rate is 1.2, when the regeneration of the population requires 2.15. (Konsepzija 2001.)

When speaking in numerical terms, the population is not composed of mothers, spouses and children. Instead, the problem is distanced from the individual citizen, thus turning it into an object that can be observed, in a rational and objective way, from an external viewpoint. In this way, the information seems impartial and impossible to be questioned. Although an abundance of statistical information appears in the material, and the demographic situation is distanced from individuals, the demographic problems are at the same time brought close to people. They are made into everyone's personal issues by using the first person plural and by talking about the problems of "our country". 
(2) We, the citizens of Russia are fewer and fewer in number every year. For several years already the population of our country has declined by 750 thousand people annually (Poslanije 2000).

(3) You know that on average the number of inhabitants in our country is reduced by almost 700 thousand people (Poslanije 2006).

When the falling birth rate is named our problem, a problem that concerns "our country", "our population", it brings the speaker and the public closer together, presenting the issue as something that concerns every individual. The use of first person plural creates an image of state leadership and people who have shared interests, while at the same time blurring possible differences of opinion between individuals belonging to the group and the hierarchical relationship between the citizens and the state leadership. In this way, individuals are presented as sharing something common to all, i.e. a serious demographic problem. Population decline appears as an individual and a collective problem simultaneously: if an individual mother does not give birth to enough children, the number of all Russian citizens as a whole will decline.

All the materials that I have studied start by stating the problem, followed by a presentation of the causes behind the problem. First, urbanization, modernization and change in the family model are presented as causes.

(4) The birth rate in the Russian Federation is defined by a massive increase in low child number families (1-2 children), birth rate measurement indicators becoming increasingly similar between urban and rural populations, delaying the birth of the first child, and an increase in the proportion of children born outside marriage (Konzepzija 2001).

Secondly, the lack of financial resources is assumed to have reduced the number of children in families.

(5) What prevents a young family, a woman, from making this choice, especially when it is about the second or third child? The answers to this question are selfevident and well known. They are low income, lack of normal living conditions. It is the doubt about one's own ability to offer the child a good level of health care, quality education. And sometimes, it is a sin to hide this, whether the woman can provide for her child. When planning to have children, a woman is forced to choose whether she should give birth and lose her job, or refuse to have the child. This is a really difficult choice. (Poslanije 2006.)

(6) Today a young family has the resources for the birth and upbringing of one child only, although the great majority of families would like to have two children. The birth of the second or third child is barely supported at all, although it is precisely these births that would make it possible to change the situation. (Nazionalnaja programma 2006.)

The lack of economic resources is presented as a self-evident reason for the falling number of children per family. In the material covered in this study, the low birth rate is problematized using economic means, as families and women are assumed to be making calculations about the economic viability of having children, and if having a 
child is not economically viable, the woman is said to refuse to give birth to the child. The birth rate is discussed as women's choice, specifically, but underlying this suggestion one can sense the idea that every woman and all families are assumed to want children, if the economic obstacles to this have been removed. The discourses that emerge from my material are used to maintain the stereotype of women as mothers who want children, and for example the personal choice of not having children is not brought up except as a choice people are forced to make because of economic necessity. This creates a model of normality, the normal woman who wants to give birth to children, if the economic conditions allow it.

In addition to causes, the material deals extensively with consequences. If there is no intervention to fix the demographic situation, the results will be dire. A drastic decline in population is presented as one obvious result.

(7) Maintaining the current level in terms of birth rate and mortality will lead to the population of our country numbering 123 million by the beginning of 2012. The loss compared to the beginning of 2006 will be 20 million people, or 1/7 of the population (Nazionalnaja programma 2006).

Predictions are used liberally in the material, and they are presented as inevitable, even though each scenario is only one possible predicted outcome. This creates an image of a danger concerning all Russians, a danger that can be objectively detected before it has materialized. An aging population, labor shortage and raising dependency ratio are presented as other consequences.

(8) The aging of the population will increase the pressure on the working population and the social and health care system, as well as promoting the escalation of problems in the payment of pensions and social benefits (Nazionalnaja programma 2006).

Elements of the problem are created by referring to the future, and negative effects in the future are explained by using mainly economic arguments, which bring up the insufficient labor force, the rise in dependency ratio, and the increase in pension and social benefit payments. The labor shortage, and the waning of economic potential resulting from it, are presented as even affecting the sovereignty of Russia.

(9) A real threat to the national security and sovereignty of Russia is connected to the reduction of working age population and the corresponding economic potential of the country ( $)$ Population decline signifies a direct threat to the national security of Russia (Nazionalnaja programma 2006).

In addition, strong nationalistic features can be seen in the way the problem is defined. First, national security is brought up, and there are references to Russian autonomy being threatened, as well as to a risk of violence. Stopping population decline is thus seen as a means of ensuring security. Perceived threats to the nation can symbolically constitute the land area towards which the threats are expected to be directed. Arguments of this type use the terminology of the geography of fear, in which the identity 
of a group of people living on particular land area is created through the fear of losing that area, and this in turn creates a desire to defend the area (Anttonen 1996). In this case, the threat that requires defenses is an internal one, i.e. the small number of children per family, which is presented as leaving the population vulnerable to an external threat in the future. Another nationalistic feature that is shown in the material is concern over the future of Russians as a nation.

(10) If the current trend continues, the survival of the nation is under threat. We risk becoming a decrepit nation (Poslanije 2000).

(11) Population decline is a serious threat, it is a challenge to our entire nation (Poslanije 2010).

A sense of unity within a nation develops when the nation is considered a fairly natural unit, one that can be justified by creating a shared history, by explaining it in biological or geographical terms, or by creating shared emotional or ritual experiences. A group of people defined as a nation usually has a shared language and culture, and it may have national autonomy, or nation state, as is the case with Russia. (Pakkasvirta and Saukkonen 2008, p.8.) In the citations I present, talk about "our nation" is clearly used in an attempt to build positive communal identity, and to spark feelings of solidarity. Although most people who are members of the Russian population do not know each other, they are presented as being in some way connected to each other, at least through being members of the nation (for comparison, see Anderson 1991). The nation appears as a natural entity that does not need further definition or justification. It is presented as having a past, but its future is being threatened because of the direction of demographic development. Creating a threat can function as an effective means to unite the nation, by organizing it to act against something. In this way, the nation has one important interest that unites it, even if closer scrutiny reveals that there are no other shared interests at all. (Bedford and Hwang 2004, p. 85.) There is similar concern over the preservation of traditions.

(12) The situation being what it is forces us to question whether the nations of Russia will be able to develop their material, spiritual and cultural potential, accumulated of several millennia (Natsionalnaja programma 2006).

In the above text sample economic, spiritual and cultural aspects are intertwined. This so-called potential is presented as valuable, unique and worthy of protection. This is about engendering nationalist sentiment, created through attachment to a variety of markers such as language, traditions of the native country, and for example culturally important works of art. Attachment to these markers builds up the identity of a nation, because these markers give the nation its distinguishing characteristics (Guibernau 1996, pp.43, 47). My interpretation is that in the Serious Problem discourse the demographic phenomenon is rendered controllable by predicting a crisis: Terrible consequences must be prevented before they become reality. Making people aware of the serious problem can be seen as an apparatus of security, in which the phenomenon 
is taken apart and its causes and consequences are presented, i.e. it is rationalized, in order to take charge of it. When the phenomenon appears clear and consistent, the solution to the problem is introduced.

(13) We must lower mortality, extend people's lifespan, beat the demographic recession (Poslanije 2004).

(14) There is consensus and shared understanding in the community about the overriding need to solve this particular key problem that concerns the whole nation (Poslanije 2006).

In the material, an obligating tone is frequently adopted in connection with solutions to the demographic situation. Similarly, as I have described above, the use of first person plural is common, creating the image that every Russian has a moral, economic and nationalist duty to participate in solving the problem, and that the state leadership is equally part of the group defined as "we". One of the text sample 14, which is presented above, contains the claim that consensus reigns in the community regarding the solution to the key problem. However, there is no further clarification on who the members of this community are, or how the consensus has been detected. The necessity of solving the problem comes up, and the option of leaving the problem to solve itself is not even mentioned. In this way, the political solutions offered to address the problem gain legitimacy.

\section{The State Support discourse}

In the Serious Problem discourse, the focus was on the object, whereas in the State Support discourse, the focus is on the subject (cp. Isola 2008). The low birth rate is presented as a problem that can be solved by demographic policy interventions, carried out by the state leadership, specifically. The involvement of the state leadership is justified by the argument that current interventions directed at the population are seen as insufficient, and developing new practices is presented as an absolute necessity.

(15) The catastrophic situation can still be changed, in the case that the state endorses and carries out a number of emergency and crisis management measures in the areas of demographic and family policies. (_) Accelerated realization of the offered interventions will slow down the population decline by the years 2012-2015, bringing it down to 270-275 thousand (instead of the 800 thousand in 2005. (Natsionalnaja programma 2006.)

(16) I propose a program for bringing up the birth rate, to be more precise: measures to support young families, and supporting those women who decide to give birth and bring up a child. In any case, in today's situation we must encourage the birth of a second child at least. (Poslanije 2006.)

The text samples convey a firm belief in the effectiveness of political decisions and measures. Even numerical information on the effectiveness of these measures is presented, lending further credibility to this particular selection of measures. It is not 
considered that the birth rate could begin to rise unless the state intervenes in the matter. The problem is suggested to be fixable by accepting the expert definition and by submitting to becoming targets to the methods of demographic policy. This equals accepting the support offered by the state leadership. Extensive knowledge regarding a serious problem, along with the expertise based on this knowledge, is one characteristic that inspires trust. The economic resources of the state leadership can be seen as another such attribute. However, I consider the most important trust-inspiring characteristic to be the goodwill of the speaker towards the entire nation, which is shown more clearly in the following example.

(17) The most important competitive capital, the most important source of development in the country - is the citizens of the country. In order for the country to become strong and wealthy, it is imperative to do everything in our power so that each person could have a normal life, each person who creates quality wares and services, creates the cultural wealth of the land, creates a new state. (Poslanije 2004.)

The image forming on the basis of the material is that the state leadership genuinely has the people's best interest at heart, and aims for this in its actions. However, supporting citizens would seem to again become just a tool to make the country rich and strong. Developing the country through increasing the number of children per family appears to be the ultimate goal of demographic policy, not for example people's happiness or parenthood per se.

Next, I will discuss different forms of support presented in the material, including a number of administrative, economic, medical and social measures. As I noted in connection with the Serious Problem discourse, economy and the demographic question are closely interconnected, and in discussions about support forms economic issues constantly rise to the forefront.

(18) In my view, the amount of financial support has the greatest effect. I feel that the state has an obligation to help a woman who has given birth to her second child and leaves the labor market for a long period, losing some of her professional skill. Unfortunately - and I feel that it is pointless to be shy about this, we must speak out on these matters if we want to solve these problems - a woman is forced to become dependent, and sometimes, to be blunt, she becomes oppressed within the family. And the state, if it is really interested in raising the birth rate, is obligated to support a woman who has made the decision to have a second child. The so-called Primary Maternity Capital must be placed under her control, which would truly raise her social status and help to solve future problems. (Poslanije 2006.)

Something clearly evident in this text sample is the building of a causal relationship between economic resources and childbirth: women have few economic resources, which causes them to give birth to few children. In other words, the conclusion is that if women are given more economic resources, they will have more children. Building causal relationships can be called argumentation based on the structure of reality, in which components of reality are connected to each other with the help of various links, 
by telling what causes certain phenomena and how they need to be changed (Perelman 1971, p.119). In the case of demographic policy, the causes of the problem have been defined using economic terminology, and attempts to affect them are made through economic means, with the help of the financial benefit called Maternity Capital. It can be seen as a metaphor that privileges certain aspects of womanhood. The metaphor gives rise to a mental image of all women possessing so-called maternal capital, or the potential to give birth to several children, although not all of them do this as a result of economic hardship. Therefore, when the state provides the woman with material maternal capital, the woman will in exchange release her childbearing maternal capital, which might otherwise remain unused.

In demographic policy programs, the suggested measures are discussed as having no alternatives, but simultaneously people are told what demographic policy should definitely not be like:

(19) Attracting immigrants from foreign states where socio-cultural parameters and lifestyles differ significantly from the socio-cultural characteristics of Russian Federation nations can help to solve economic problems only temporarily and locally, while at the same time causing, however, social instability in the near future. The quality of natural modern immigration processes from various regions (Southern parts of Russia, Middle East) does not correspond to the economic and political interests of the state. (Natsionalnaja programma 2006.)

(20) Any type of immigration will not solve our demographic problems, unless we create appropriate conditions and incentives to improve the birth rate, among us, in our very own country. Unless we carry out effective programs to support motherhood, childhood and family. (Poslanije 2006.)

Multiculturalism is seen as a cause of instability, and immigrants' lifestyles are presented as differing substantially from the customs of Russian Federation nations. Immigration processes are described as not corresponding to the economic and political interests of the state. Underlying these speeches seems to be the idea that a stable society is based on shared values, a shared ethnic origin and a shared culture. Immigration is presented as threatening this basis. Therefore, it is not considered among the possible solutions. Immigration is not presented as an option even in the case that raising the domestic birth rate fails. Only the birth of Russian people's own children is presented as desirable. According to the National Program, a third option after raising the birth rate and increasing the average lifetime expectancy is:

(21) Convincing Russians and Russian-speaking residents of former Soviet Union Republics to move into the Russian Federation (Natsionalnaja programma 2006).

In allowing immigration the limit is drawn at residents of former Soviet states who speak Russian and Russians living abroad. When the possible solutions regarding demographic policy have been presented and justified, the next step is encouragement, which states that the interventions will work. 
(22) I am certain that our community has the strength to solve these problems and gradually stabilize the numbers of the Russian population (Poslanije 2003).

A frequently emerging theme in this material is the faith of Russian decision-makers in the effectiveness of demographic policy. This is done in an attempt to portray the reliability and infallibility of the interventions. However, the state leadership by itself cannot change the demographic situation. As is obvious in the following text sample, the aim is to commit all citizens to shared goals that the state leadership has created.

(25) Our nation has fought against slavery, fought for the right to live in its own country, for the right to speak its own mother tongue, for its state, culture and traditions. It has fought for justice and freedom. It has attained the right to independent development. Thus it gave out Fatherland its future. And it is up to the current generations, us and you, what shape that future will take. (Poslanije 2005.)

Nostalgic, backward-looking idealization of past battles is used as a tool to build unity and to commit people to the goals of demographic policy. In a sentimental tone, everyone is invited to participate. When the heroic feats of the older generations are described, the image emerges that anyone who does not commit to these demographic goals is a traitor.

\section{The Family Centered discourse}

The texts convey a sense of emphasizing maternity as the solution to the birth rate problem, but they also clearly show presentation of the family as part of the problem solving process. I have named this narrative the Family Centered discourse, because I see this aptly reflects the meanings conveyed by this narrative, the most obvious of which is the idealization of traditional family values. By this I mean the highlighting of the family as a harmonious and natural lifestyle, and the definition of marriage as a union between one man and one woman, which forms the basis for a family, with the ultimate purpose of producing and raising offspring. In this discourse, it becomes more obvious than anywhere else that demographic policy intrudes deep into the personal sphere of individual citizens, as political measures are connected to emotions and the meaning of life.

(24) And now we are talking about the most important matter. (---) What is the most important thing in life? This is about love, women, children. About family. (Poslanije 2006.)

(25) The problems of economic and social development in our country are intimately tied to a simple question: what are we doing all this for? (Poslanije 2006).

The examples discuss the meaning of life, with the expectation that the family is at its center. Love and having children are likewise connected to the family. The question in text sample 25, asking what we do all this for, can be interpreted as meaning that life is meaningless without future generations, and that purpose in life is based on traditional family life and having children. Text sample 24 refers to love, which may function as a good means of persuading people, because no one will be likely 
to criticize its significance offhand. Defining it in greater detail does of course make its generality disappear, but in this context it functions as a uniting factor between the speaker and the audience, creating an impression of the purity of the speaker's motives. Love and happiness are usually valued more highly than competitiveness, and appealing to love functions as a more compelling argument to most people than appealing to economic factors. It is reasonable to assume that all people do not consider maintaining economic competitiveness to be important, but resisting the good of society and the individual would be hard for anyone. Thus demographic policy is presented as something humane: it is not calculated intrusion into the private sphere of life, but sincere action with the aim of promoting the well-being and happiness of both individuals and the nation. In the following sample, the birth rate issue is also linked to love for the native country.

(26) In conclusion, I wish to emphasize this: the problem of low birth rate cannot be solved without the entire society changing its attitudes toward the family and family values. In the distant past, the academician Lihatsev wrote that love for your place of birth, love for your homeland, starts with love for your own family. And we must return our old values, appreciation for family and the haven of home. (Poslanije 2006.)

In this material, family is presented as a self-evident norm, which may have slipped the mind of the modern person. The issue thus revolves around emphasizing the traditional family, a traditional family ideology that receives support from influential parties in society. The sentence "love for your homeland starts with love for your own family" highlights the societal importance of the family. According to Foucault, influencing the family is one of the means by which the population is pushed to behave in a desired way. In this process, the instrumentality of the family becomes obvious, instead of the family being valuable in itself. In this case it means that the goal of demographic policy, i.e. raising the birth rate, cannot be seen as happening without strengthening the family values (see Foucault 2007, p.112). This can be clearly seen in the following sample which presents the goals of Russia's national demographic policy, consisting of:

(27) strengthening the family as a social institution, reviving and preserving those patriotic spiritual-moral traditions that are connected to family relations, family upbringing, orientation of the population towards broad demographic productivity, and permanent improvement in the demographic indicators of the population (Natsionalnaja programma 2006).

Hence, there is a desire to support the family so that it could become oriented towards broad demographic productivity. The goal is to set the family up as a desirable and acceptable norm, and compliance with this norm is seen as leading to the fulfillment of the goals of demographic policy. In the State Support discourse, the state-supplied financial and health-related support forms were discussed, but in addition to these, efforts are made to influence people's attitudes. 
(28) An important role in the distribution of information regarding demographic development must be given to the media. Providing regular, detailed information in the media regarding themes such as healthy lifestyles, the status of an active citizen, optimistic approach to life, and the rational stereotypes of the people's behavior in different life situations, as well as raising the prestige of a stable, communal family, is the most important aspect of carrying out the concept successfully. (Kontseptsija 2001.)

The state leadership gives the media the task of distributing information and stereotypes of a certain kind of behavior, trying to steer the recipients' opinions in a direction more accepting of families and having children, in order to turn the society's demographic development upward. However, the distribution of information is presented in a positive tone, with the intention of educating the citizens and steering them to the right path. In addition to distributing information in the media, attitudes are shaped in other ways too.

(29) In this connection, I would like to express my support to the initiative of declaring the year 2008 the Year of the Family in Russia. I assume that celebrating this year will enable connecting the aspirations of state, community and business around the most important issues, those concerning strengthening the authority of the family, and supporting the family institution and fundamental family values (Poslanije 2007).

Announcing the Year of the Family can be seen as placing the family at the hub of society, meaning that efforts are made to link the state leadership, ordinary citizens and actors in the private sector to a shared goal, i.e. reviving the family institution. However, as has been described above, the family institution is only an indirect goal, since the ultimate goal is giving birth to children, and not only one but several children.

(30) According to experts, the most important road to overcoming the demographic crisis - is a radical increase in the number of families with at least three children (Poslanije 2010).

The issue is thus one of favoring families with many children. As was shown above, the Maternity Capital benefit can only be received if the woman has had at least one child previously. Also, during the Year of the Family, large posters of mothers and families with three children were displayed in public places. Alongside this, in 2009 medals started to be awarded to large families. These medals are given to parents of biological or adopted children who have a minimum of seven children.

(31) For two years now we have awarded the "Honor of Parenthood" medal, established on my initiative. Among the fathers and mothers who have received the medal are not only parents of their own children, but also parents of adopted children. As is right and proper, we are proud of such families. And I must openly confess that just interacting with them brings true joy, when they come here, to the Kreml, to receive these national badges of honor. (Poslanije 2010.) 
The text sample reveals the idealization of parenthood, which is supported by the public award ceremony. This strengthens the image of a large family and raising children, portraying them as a desirable and praiseworthy way of life. In addition, the president expresses his own positive regard families, and this is established as the norm. The text sample also mentions parents of adopted children, but not families with samesex parents. Neither is there any discussion on considering the needs of new types of families. Instead, there is a desire to bring back the traditional family, with oppositesex parents and several children.

One aspect that comes up in the Family Centered discourse is a desire to preserve the traditional societal order and family institution. Examples of desirable behavior are used as part of the discourse, and everything is supposed to be brought back to such behavior. There are attempts to revive the family institution, not by force, but rather by setting acceptable boundary conditions, which agree with the traditional family ideology.

It is also worth mentioning that in all of the documents I have studied there are no much references to the unwed parents, divorces or single mothers. So even though only the traditional family is discussed, other form of parenting, such as single-mothers and enlarged families, are not completely excluded from discussion and state support, although family is presented as a basic units of society (cp. Isola 2008; Rotkirch et al. 2007).

\section{Discussion}

In this article, I have discussed the formation of Russian demographic policy in the years 2000-2010. The focus of my interest has been on the ways that demographic policy is conceptualized and made comprehensible. As a result of my analysis, I have named different discourses that are used in the representation of the demographic situation and the demographic policy based interventions carried out by the state leadership. I believe that these three different discourses highlight different aspects of a single, broader demographic policy discourse, and are parts of it.

In the Serious Problem discourse, efforts are made to prove the seriousness of the problem by presenting statistics, by referring to authorities, and by using first person plural, through which the problem is defined as social, economic, regional and cultural, and it appears as something concerning every citizen. In this discourse, the demographic phenomenon has been taken apart and rationalized by presenting its causes and consequences. The Serious Problem discourse is about creating crisis awareness. The adopted viewpoint is in a possible future, and people are told what will happen if the birth rate remains at its current level; Russia's economic position will be weakened, social problems will develop and the sovereignty of the state will become threatened. Predicting the future is difficult, but the material does not discuss possible outcomes or estimates. Instead, predictions of the future are presented as clear facts that rule out all competing interpretations, with no reservations attached. The use of power by the 
state leadership is legitimized through the definition of the problem, i.e. the problem is in a sense taken into possession by defining it. When certain causes for the problem have been presented, certain specific modes of action become possible solutions.

While the Serious Problem discourse creates an image of a problem that has to be solved, the State Support discourse presents the means to solve the problem, means that are under the control of the state leadership. The actions of the state leadership are justified by claiming that the state leadership knows what it is doing, its previous measures have been successful, and its motives are righteous and genuine. Faith in the effectiveness of political action is therefore strong. In the State Support discourse, economic support is presented as the most effective means of raising the birth rate, and a causal relationship is built between childbirth and the economic resources under a woman's control. Regulation of the birth rate is seen as being in the hands of women especially, so the demographic policy based support forms are primarily targeted at them.

In the Family Centered discourse, the traditional family model is represented as a virtue and as the natural mode of life for the individual, because in this form of family it is possible to experience love, and because it is an absolute necessity for demographic interventions to succeed and the society to be preserved. The family itself is presented as important, but there is a clearly detectable underlying idea that strengthening the family institution will help to attain the goals of demographic policy. In this discourse, the family is defined ideologically as a union of two opposite-sex people resulting in the birth of several children. The family is not placed at the hub of demographic policy only by means of concrete demographic decrees and support forms, but also by using educational-propagandist tools: public emphasis on family values, awarding "Honor of Parenthood" medals, and announcing the year 2008 to be "the Year of the Family".

It is noteworthy that in this material there is no discussion at all of the requirements of educational and working life sectors, but only of women's choice of not giving birth to children due to lack of financial resources. The solution is thus seen as residing with women. Although the documents talk about the young family, they do not talk much about men or about couples making decisions about having children together. In addition, it would be possible to look for causes for not having children in men's choices, e.g. in excessive alcohol consumption, but this is not done. The woman is presented as an active subject, while the man remains passively in the background. Blame is not exactly laid on women. Quite the opposite, their situation is understood and efforts are made to support them, so that they could carry out the task that they are presented as wanting for themselves, i.e. giving birth to more children (cp. Rivkin-Fish 2010). Attempts to influence the birth rate are targeted mainly at women, but women themselves do not participate in defining the kind of help they need.

The discourses that emerge from different documents do not contradict each other. The different documents in the analyzed material unanimously emphasize shared 
causes, the ones described above. Thus the "understandable" causes of the demographic problem that are presented in different contexts appear as self-evident and simple. Analyzing the suggested causes forms a central part of my analysis, because presentation of the causes is linked to the kinds of alternatives that are presented as solutions to the problem.

The discourses I have analyzed contain an abundance of nationalistic features: first, it is notable that in this material the population decline is turned into a national issue, separated from the global demographic situation and the population growth problems of developing countries. The rest of the world is not even discussed, nor is it seen to bear any relation to Russia's demographic problem. Secondly, immigration is seen as the last-resort option as opposed to domestic birth rate, and multiculturality is noted to cause unrest in the society. Thirdly, in the speeches urging people to propagate, references are often made to history and great battles of the past on behalf of the nation and the homeland.

I saw that it was appropriate to discuss documents of the state leadership in this study, because of their societal significance and wide distribution. In the material I have studied, the state leadership presents itself as a ruler of the truth, with pure motives, wanting to guide its people. Nevertheless, I find these discourses problematic, first in the sense that they produce a very one-sided image of womanhood, family and desirable ways of life. Secondly, demographic policy is mainly exercised in a centrally managed fashion, from above, meaning that the people it targets have not participated in defining their own support needs. People are thus more or less invited to conform to the predefined models that the state leadership is offering, and the people's own or their communities' opportunities to influence matters are not supported. It would seem, however, that the primary interest in Russian demographic policy is not in people as individuals, but in the population as a whole. Even then the interest is not directed at the welfare of the population as such, but mainly at the opportunities of instrumentalizing this welfare and making it a means of producing economic affluence.

In this discourse analytic study, my interest has focused on linguistic constructions and the presumptions underlying them. I have aimed to analyze these in the context of the topic called demographic policy. Although I have discussed the Russian situation, specifically, I have a broader interest in this topic. However, I feel that Russia has provided a useful example, because in this country the aim has been to present the demographic situation as extremely acute. Although other industrialized countries are equally characterized by low birth rates, in Russia the situation is complicated by high mortality. In a nationalistic atmosphere this has lead to an interesting state of affairs where concern is expressed over the insufficient numbers of the country's own population, while at the same time the planet is threatened by a population explosion. 


\section{References}

Aarva, P. and I. Pietilä. 2010. Russian health in transition. In: Wittnessing Change in Contemporary Russia, edited by T. Huttunen and M. Ylikangas. Vaajakoski: Kikimora Publications Series B 38. WS Bookwell, 221-249.

Anderson, B. 1991. Imagined communities: Reflections on the Origin and Spread of Nationalism. London: Verso.

Anttonen, P. 1996. Myyttiset uhkakuvat ja puolustuseetos Suomen ja suomalaisuuden konstituoinnissa [Mythical threats and defence ethos in the construction of Finland and finnishness]. Elektroloristi 3(2). [cited 12 February 2009]. Available. from: http://www.elore.fi/arkisto/2_96/ant296.html

Bedford, O and K. Hwang. 2004. Taiwanese identity and democracy. New York: Palgrave, Macmillian.

Elizarov, V. 2002a. Demografitšeskij krizis v Rossii. Faktory i posledstvija [Demographic crisis in Russia. Factors and consequences]. Gosudarstvo i antropotok. [cited 12 February 2010]. Available from: http://www.antropotok.archipelag.ru/ text/a115.htm

Elizarov, V. 2002b. Ekonomitšeskaja podderžka semji v Rossijskoi Federatsii [Economical support for the family in the Russian Federation]. Demoskop weekly. [cited 12 February 2010]. Available from: URL:http://demoscope.ru/ weekly/2002/051/polit02.php

Fairclough, N. 1995. Media discourse. London: Edward Arnold.

$\mathrm{FE}=$ Filosofskaja entsiklopedija [Philosophical dictionary]. [cited 12 February 2010]. Available. from: http://dic.academic.ru/contents.nsf/enc_philosophy/

Foucault, M. 1978. The History of Sexuality. Vol 1. An Introduction. London: Lane.

Foucault, M. 2007. Security, Territory, Population. History of govermentality. Lectures in Collège de France 1977-1978. Basingstoke: Palgrave Macmillan.

Guibernau, M. 1996. Nationalisms. The Nation State and Nationalisms in the Twentieth Century. Cambridge: Polity Press.

Halturina, D. and A. Korotaev. 2006. Russkij Krest: Faktory, mehanizmy i puti preodolenija demografitšeskogo krizisa [Russian cross: Factors, mechanisms and ways to overcome demographic crisis]. Moskva: KomKniga.

Hartšenko, L .2009. Demografia [Demography]. Moskva:”Omega- L”.

Isola, A-M. 2007. Fertility Concern in Finland and Russia: economic thinking and ideal family size in the rhetoric of population policies. Yearbook of Population Research in Finland 43 (2007-2008), 63-4.

Isola, A-M. 2008. Tyttärien vastuu. Terveyshuoli osana Venäjän alhaisen syntyvyyden retoriikkaa. [Responsibilieties of daughters. Worry about health as part of rhetoric of low birthrate]. Yhteiskuntapolitiikka YP 73(5): 524-537.

Jarošinskaja, A. 2007. Ob istorii migratsii i migratsionnoi politiki v Rossii. [On the history of migration and migration policy in Russia]. Rosbalt. [cited 12 February 2010]. Available from: URL:http://demoscope.ru/weekly/2007/0297/gazeta010.php

Lehtonen, M. 1996. Merkitysten maailma [The world of meanings]. Tampere: Vastapaino. 
Pakkasvirta, J. and P. Saukkonen. 2000. Nationalismi teoreettisen tutkimuksen kohteena [Nationalism as an object of theoretical research]. In: Nationalismit, edited by J. Pakkasvirta and P. Saukkonen. Helsinki: WSOY.

Pensionnij Fond. 2011. Informatsija o materinskom kapitale [Information about Maternity Capital]. [Cited 4 October.2009]. Available from: URL:http://www.pfrf. ru/family_capital/

Pensionnij Fond [Cited 4 June 2011]. Available from: URL:http://www.pfrf.ru/

Perelman, C. 1971. The new rhetoric. A treartise on argumentation. Notre Dame (IN):

University of Notre Dame Press.

Population Reference Bureau. Fertility Rates for Low Birth-Rate Countries, 1995 to Most Recent Year 2000-2011. [Cited 4 October 2009]. Available from: URL:http:// www.prb.org/pdf07/TFRTable.pdf

Prioritetnij natsionalnij projekt 2007. Zdorovje. [Priority National Project. Health]

[Cited 4 October 2009]. Available from: URL:http://www.rost.ru/projects/health/ p01/p11/a11.shtml

Prioritetnij natsionalnij projekt 2008. God semji.[Priority National Project. Year of the Family] [Cited 4 October 2009]. Available from: URL:http://www.rost.ru/main/ family.shtml

Rapo, M. 2008. Väestöennusteet ovat aina aliarvioineet eliniän pitenemisen. [Population prognoses has always underestimated growth in life expectancy]. Hyvinvointikatsaus-Kulutus. 2009, 4. [Cited 4 October 2009]. Available from: URL:http://www.stat.fi/tup/hyvinvointikatsaus/hyka_2009_04.html

Rivkin-Fish, Michele. 2010. Pronatalism, Gender Politics, and the Renewal of Family Support in Russia: Towards a Feminist Anthropology of 'Maternity Capital'. Slavic Review 69(3): 701-724.

Rosstat $=$ Federalnaja služba gosudarstvennoi statistiki [Federal service of governmental statisticsia]. Naselenije 2000-2011. [Cited 17 October.2009]. Available from: URL:http://www.gks.ru/wps/portal/russian

Rotkirch, Anna, Anna Temkina and Elena Zdravomyslova. 2007. Who Helps the Degraded Housewife? Comments on Vladimir Putin's Demographic Speech. European Journal of Women's Studies 14(4): 349-357.

Sidorina, T. 2005. Dva veka sotsialnoi politiki [Two centuries of social policy]. Moskva: Possiiskii gosudarstvennii gumanitarnii universitet.

Smirnov, S and T. Sidorova. 2004. Sotsialnaja politika [Social policy]. Moskva: Izdatelskii dom GU VSE.

Tilastokeskus. 2010. Syntyneet. Kokonaishedelmällisyysluku maakunnittain 20002010. [Births. Total fertility rate by regions 2000-1010]. [Cited 1 September 2012]. Available from: URL:http://www.stat.fi/til/synt/2010/synt_2010_2011-0415_tie_001_fi.html

Ulkoasiaministeriö. 2011. Suomen ja Venäjän välinen sosiaali- ja terveysalan lähialueyhteistyö vuosina 2004-2009 [Finnish-Russian social and healthcare collaboration between adjacent regions in the years 2004-2009]. Edita Oyj.

UN. 2008. Demokrafitšeskaja politika Rossii: ot razmišlenij k deistvijam [Demographic policy in Russia: from thinking to action]. Moskva. 
U.S. Census Bureau. The Population Estimates Program 2007. [Cited 4 October 2009]. Available from: URL:http://www.census.gov/

Vallin, J., E. Andreev, F. Meske, and V. Shkolnikov. 2005. Geographical diversity of cause-of-death patterns and trends in Russia, Demographic Research 12 (13). . [Cited 26 August 2012]. Available from: URL:http://www.demographic-research. org/Volumes/Vol12/13/12-13.pdf

Višnevskij, A. 2009. Demografitšeskij krizis v Rossii [Demographic crisis in Russia]. Moskva: Tsentr Rossija/NNG.

Volkov, A. 1999. Evoljutsija rossijskoi semji v XX veke [Evolution of Russian family]. Mir Rossii, 199 (4).

Vuori, J. 2001. Äidit, isät ja ammattilaiset. Sukupuoli, toisto ja muunnelmat asiantuntijoiden kirjoituksissa [Mothers, fathers and professionals. Gender, reiteration and variations in the writings of professionals]. Tampere: Tampere University Press.

Zakharov, S., and E. Ivanova. 2004. Fertility Decline and Recent Changes in Russia: On the Threshold of the Second Demographic Transition. In Russia's Demographic "Crisis". Edited by DaVanzo, J. Santa Monica, CA: RAND.

Zaharov, S. 2005. Perspektivy rošdajemosti v Rossii: vtoroi demografitšeskij perehod [Perspektives of birth rates in Russia: second demographic transition].Otetšestvennije zapiski. 2005, 3 (24).

\section{Laws and Decrees:}

Law 28.12.2001. Federalnij zakon o vnesenii izmenenij v Federalnij zakon "o gosudarstvennih posobijah graždanam, imejuštših detei" [Alterations to the law on governmental benefits for citizens with children]. Moskva: Rossijskaja Federazija.

Law 29.12.2006. Federalnij zakon o dopolnitelnih merah gusudarstvennoij podderžki semjei, imejuštših detej [Federal law concerning additional governmental support for families with children]. Moskva: Rossijskaja Federazija.

Decree 1.1.2006. Prioritetnij natsionalnij projekt "Zdorovje" [The national project "Health"]. Moskva: Kreml.

Decree 1.1.2006. Rodovoi sertifikat [Childbirth Certificate]. Moskva: Kreml.

Decree 14.6.2007. Ukaz prezidenta Rossijskoi Federatsii. [Declaration by the President of the Russian Federation]. Moskva: Kreml.

\section{Used data:}

Poslanije Prezidenta federalnomu sobraniju 2000-2010. [Presentations by Russian Presidents to the Federal Assembly of the Russian Federation in the years 2000 2010]. [Cited 26 August 2012]. Available from: URL:http://kremlin.ru/acts

Kontseptsija demografitšeskogo pazvitija Rossijskoi Federatsiji na period do 2015 goda. [Consept of demographic development of the Russian Federation until 2015]. [Cited 26 August 2012]. Available from: URL:http://www.demoscope.ru/weekly/ knigi/koncepciya/koncepciya.html 
Kontseptsija demografitšeskogo pazvitija Rossijskoi Federatsiji na period do 2025 goda. [Consept of demographic development of the Russian Federation until 2025]. [Cited 26 August 2012]. Available from: URL:http://demoscope.ru/weekly/knigi/ koncepciya/koncepciya25.html

Natsionalnaja programma demografitšeskogo razvitija Rossii. [The national program for the demographic development of Russia]. [Cited 26 August 2012]. Available from: http://www.demographia.ru/articles_N/index.html?idR=5\&idArt=378 